\title{
Analysis of application and diagnostic importance of Alvarado scoring system in patients with right lower quadrant abdominal pain
}

\author{
Sanjay N. Koppad*, Harsha Kodliwadmath, Mallikarjun Desai
}

Department of General Surgery, SDM College of Medical Sciences, Sattur, Dharwad, Karnataka, India

Received: 03 May 2016

Accepted: 09 May 2016

*Correspondence:

Dr. Sanjay N. Koppad,

E-mail: sanjaykoppad@gmail.com

Copyright: ( $)$ the author(s), publisher and licensee Medip Academy. This is an open-access article distributed under the terms of the Creative Commons Attribution Non-Commercial License, which permits unrestricted non-commercial use, distribution, and reproduction in any medium, provided the original work is properly cited.

\begin{abstract}
Background: Acute Appendicitis is a common emergency condition requiring surgical intervention. Accurate diagnosis is the deciding factor in reducing the morbidity and mortality associated with the illness and is also the key to avoid unnecessary appendectomies. In this study we analyse the clinical efficacy of modified Alvarado scoring in diagnosing acute appendicitis

Methods: In a prospective non-randomized study including 99 patients presenting with acute onset right lower abdominal pain from to were included in study in whom the alvarado score was obtained at admission and categorized into three groups and group 3 and group 2 patients with deterioration underwent emergency appendicectomy compared with histo-pathological diagnosis. Sensitivity, specificity, positive predictive value, negative predictive value and negative appendicectomy rate calculated.

Results: In our study, overall sensitivity and specificity were $98.50 \%$ and $87.09 \%$ respectively. Positive and negative predictive values were $94.36 \%$ and 96.42 respectively. Overall Negative appendicectomy rate in our study was $5.9 \%$.

Conclusions: We conclude that Alvarado scoring system is easy, simple, cheap and useful tool in pre-operative diagnosis of acute appendicitis which can be used in the community by general practitioner and residents in the referral hospitals. Scores more than seven virtually confirm the diagnosis of acute appendicitis and early operation is indicated.
\end{abstract}

Keywords: Appendicitis scoring, Perforated appendix, Faecal peritonitis, Ultrasound abdomen, Right lower quadrant pain

\section{INTRODUCTION}

Right lower quadrant abdominal pain is one of the most common presenting symptoms in surgical outpatient department. Acute appendicitis is the most frequent diagnosis in these patients. Clinical diagnosis is the crux in these patients despite advances in imaging modalities. In 1886 Fitz described classical sign and symptoms of acute appendicitis. ${ }^{1}$ Earlier approach was when in doubt take it out. Overall negative appendicectomy rate prevailed at $20 \%$ for decades. ${ }^{2}$ This has led to increased morbidity and financial cost of treatment. Investigations including Ultrasound, CT scan and even diagnostic laparoscopy have been suggested to reduce the negative appendicectomy rate. Alvarado scoring system was introduced in $1986 .{ }^{3}$ It is based purely on history, clinical examination; simple laboratory tests and is easy to apply.

\section{METHODS}

This study was carried out at the Department of General Surgery, Rural Medical College, Loni, from 12/8/12 to 
9/8/13. All patients with pain in Right Iliac Fossa (RIF) were considered for the study irrespective of signs and severity. Alvarado scoring (Table 1) was documented by the Surgery resident in every case at presentation, subsequently patients were divided into three groups based on score obtained. Group I - score one to four, Group II score five to six, Group III score seven to. Group I: Patients were treated on outpatient basis and asked to follow up. Group II: Admitted and observed for 24 hours, treated with Oshner - sherian (O-S) regimen. Deterioration in scores by more than two was taken up for surgery. Group III: Taken up for emergency surgery. All specimens were sent for histo-pathological examination and confirmation of diagnosis. The sensitivity, positive predictive value, specificity, negative predictive value, negative appendectomy rate was calculated out in order to assess the reliability of Alvarado score.

We aimed at analysing the Alvarado Score in patients with right iliac fossa pain to diagnose acute appendicitis accurately and its importance in ruling out negative appendicectomy.

\section{RESULTS}

Table 1: Alvarado scoring system.

\begin{tabular}{|ll|}
\hline Criteria & Score \\
\hline Symptoms & \\
\hline Migratory RIF pain & 1 \\
\hline Nausea and vomiting & 1 \\
\hline Anorexia & 1 \\
\hline Signs & \\
\hline RIF Tenderness & 2 \\
\hline Fever & 1 \\
\hline Rebound RIF tenderness & 1 \\
\hline Laboratory Tests & \\
\hline Leukocytosis & 2 \\
\hline Neutrophilic Left Shift & 1 \\
\hline Total Score & 10 \\
\hline
\end{tabular}

Group - I; score 1-4, Group - II; score 5-6, Group -III; score 710.

Table 2: Age distribution of patients in our study.

\begin{tabular}{|ll|}
\hline AGE & Number of patients \\
\hline $0-10$ & 5 \\
\hline $11-20$ & 27 \\
\hline $21-30$ & 30 \\
\hline $31-40$ & 11 \\
\hline $41-50$ & 16 \\
\hline $51-60$ & 4 \\
\hline $61-70$ & 4 \\
\hline $71-80$ & 2 \\
\hline Total & 99 \\
\hline
\end{tabular}

Table 3: Operative findings and histopathology reports in our study.

\begin{tabular}{|ll|}
\hline Histopathology report & Number of patients \\
\hline Acute appendicitis & 51 \\
\hline Gangrenous appendicitis & 1 \\
\hline Chronic appendicitis & 10 \\
\hline Perforated appendicitis & 2 \\
\hline Appendicular abscess & 3 \\
\hline No specific pathology & 2 \\
\hline Gangrenous intestine & 1 \\
\hline Salpingo-oophoritis & 1 \\
\hline Total & 71 \\
\hline
\end{tabular}

Table 4: Statistical analysis in male patients.

\begin{tabular}{|llll|}
\hline $\begin{array}{l}\text { Diagnostic } \\
\text { test result }\end{array}$ & $\begin{array}{l}\text { Conformed } \\
\text { appendicitis }\end{array}$ & $\begin{array}{l}\text { No- } \\
\text { appendicitis }\end{array}$ & Total \\
\hline Positive & True Positive - 36 & $\begin{array}{l}\text { False positive } \\
-0\end{array}$ & 36 \\
\hline Negative & False Negative - 1 & $\begin{array}{l}\text { True } \\
\text { Negative-17 }\end{array}$ & 18 \\
\hline Total & 37 & 17 & 54 \\
\hline
\end{tabular}

Sensitivity: $97.29 \%$

Predictive value of positive test: $100 \%$

Specificity: $100 \%$

Predictive value of negative test: $94.44 \%$

Negative appendicectomy rate: $0 \%$

Table 5: Statistical analysis in female patients.

\begin{tabular}{|llll|}
\hline $\begin{array}{l}\text { Diagnostic } \\
\text { test result }\end{array}$ & $\begin{array}{l}\text { Confirmed } \\
\text { appendicitis }\end{array}$ & $\begin{array}{l}\text { No - } \\
\text { appendicitis }\end{array}$ & Total \\
\hline Positive & $\begin{array}{l}\text { True } \\
\text { positive }-31\end{array}$ & False positive -4 & 35 \\
\hline Negative & $\begin{array}{l}\text { False } \\
\text { negative - } 0\end{array}$ & $\begin{array}{l}\text { True negative - } \\
10\end{array}$ & 10 \\
\hline Total & 31 & 14 & 45 \\
\hline
\end{tabular}

Sensitivity: $100 \%$

Predictive Value of Positive Test: $88.5 \%$

Specificity: $71.42 \%$

Predictive Value of Negative test: $100 \%$

Negative Appendicectomy Rate: $11.4 \%$

Table 6: Observed overall indices of our study.

\begin{tabular}{|llll|}
\hline $\begin{array}{l}\text { Diagnostic } \\
\text { Test } \\
\text { Result }\end{array}$ & $\begin{array}{l}\text { Confirmed } \\
\text { Appendicitis }\end{array}$ & $\begin{array}{l}\text { No - } \\
\text { Appendicitis }\end{array}$ & Total \\
\hline Positive & $\begin{array}{l}\text { True Positive } \\
(67)\end{array}$ & $\begin{array}{l}\text { False Positive } \\
(4)\end{array}$ & 71 \\
\hline Negative & $\begin{array}{l}\text { False Negative } \\
(1)\end{array}$ & $\begin{array}{l}\text { True Negative } \\
(27)\end{array}$ & 28 \\
\hline Total & 68 & 31 & 99 \\
\hline
\end{tabular}

Sensitivity: $98.5 \%$; Predictive Value of Positive Test: $94.36 \%$

Specificity: $87.09 \%$; Predictive Value of Negative Test: $96.42 \%$ Negative Appendicectomy Rate: 5.9\% 
Total of 99 patients included in the study, with 54 male $54.54 \%$ and 45 female $45.45 \%$. Mean age of Patients was 30.8 with a range of $0-80$ years (Table 2). Based on Alvarado scoring at presentation, 15 patients $(15.15 \%)$ were categorized into Group I. Number of patients in Group II were $13(13.13 \%)$. Group III had a total 71 patients $(71.71 \%)$. Sex distribution was 10 males $(66.6 \%)$ and five $(33.33 \%)$ females in Group I, nine males $(69.3 \%)$ and four females $30.7 \%$ in Group II, 35 (50.7\%) males and $36(49.29 \%)$ females in Group III. All 71 patients in Group III were operated. Acute appendicitis was confirmed histo-pathologically in 67 patients. No pathology was detected in two female patients, gangrenous intestine in one female patient and salpingooophritis in one female patient (Table 3). In Group II 7 out of 13 patients were operated. Acute appendicitis was confirmed in one patient, psoas abscess in three patients (two female and one male), and intussusception in one female patient and tubercular peritonitis in two patients (one male and one female). In males the sensitivity and specificity were $97.29 \%$ and $100 \%$ and positive and negative predictive value was $100 \%$ and $94.44 \%$ respectively (Table 4). In females the sensitivity and specificity were $100 \%$ and $71.42 \%$, positive and negative predictive values were $88.5 \%$ and $100 \%$ respectively. Negative appendectomy rate in males $0 \%$ and in females $11.4 \%$ (Table 5). The Overall sensitivity and specificity was $98.50 \%$ and $87.09 \%$ and positive and negative predictive value was $94.36 \%$ and 96.42 respectively (Table 6). Overall Negative appendicectomy rate in our study was $5.9 \%$.

\section{DISCUSSION}

Decision making in acute appendicitis poses a challenge in developing countries where radiological investigations are not available/cost effective. Negative appendicectomy rate of $25 \%$ and $35-45 \%$ in males and females respectively have been found in studies conducted earlier by Dunn et al, Lewis et al with diagnostic accuracy (75 $\%)$ much less than our study and negative appendicectomy rate much more than our study in males and females. ${ }^{4,5}$ Clinical scoring systems devised by Teicher et al, Lindberg and Feyo, Ramirez and Dens J, all had sensitivity ranging from 48 to $77 \%$ while specificity of 73 to $87 \%$, which is less than Sensitivity of our study ( $98.5 \%$ ) while specificity is nearly $(87.09 \%){ }^{6-8}$ Kalan et al using modified version of Alvarado score found negative. ${ }^{9}$ Appendicectomy of $14.6 \%$, sensitivity of $93 \%$ in males and $67 \%$ in female. Our study shows a positive predictive value of $(94.36 \%)$ comparable with literature reports of $97 \%, 97.6 \%, 83.5 \% .^{10-12} \mathrm{We}$ had a negative appendicitis rate of $5.9 \%$, Similar results were reported in literature $21 \%, 15.6 \%, 7 \% .^{10-12}$ This is a simple scoring system which can be easily interpreted by non-surgicalresidents. ${ }^{13}$

\section{CONCLUSION}

Acute appendicitis is a diagnostic challenge for the surgeon in spite of having radiological investigations in the modern era; there is no laboratory or radiological test which can reliably diagnose the condition. Alvarado scoring system is easy, simple, cheap, useful tool in preoperative diagnosis of acute appendicitis. Scores more than seven virtual confirm the diagnosis of acute appendicitis and early operation is indicated. For this reason the scoring system could be safely used by general practitioners in deciding whether to refer a patient to hospital for surgical treatment. Patients with score fivesix must be admitted and observed by frequent assessment of Alvarado scoring.

\section{ACKNOWLEDGEMENTS}

SDM College of Medical Sciences, Sattur, Dharwad, Karnataka, India.

\section{Funding: No funding sources}

Conflict of interest: None declared

Ethical approval: The study was approved by the institutional ethics committee

\section{REFERENCES}

1. Fitz RH. Perforating inflamation of the vermiform appendix with special reference to its early diagnosis and treatment.Am J Med Sci. 1986;92:321-46.

2. Hobson T, Rosenman LD. Acute Appendicitis: when is it right to be wrong?Am J Surg. 1964;108:306-11.

3. Alvardo A. A pracitical score for early diagnosis of acute appendicitis.AnnEmerg Med. 1986;15:557-64.

4. Dunn EL, Murphy JR. The unnecessary laprotomy for appendicitis:can it be decreased?Am Surg. 1982;48:320-3.

5. Lewis FR, Hocolt JW. Appendicitis: a critical review of diagnosis and treatment in 1000 cases. ArchSurg. 1975;110:677-84.

6. Teicher IRA,Cohen M. Soring system to aid in diagnosis of appendicitis.AnnSurg. 1983;198:753-9.

7. Lindberg G, Fenyo G. Algorithimic diagnosis of appendicitis using bayes theoramand logistic regression.in: bayesian statistics $3^{\text {rd }}$ ed. Bernardo JM, Degroot MH. Proceedings if the third Valencia international meeting oxford: Clarendon Press; 1988:665-668.

8. Ramirez JM, Dens J. Practical score to aid decision making in doubtful cases of appendicitis Br J Surj. 1994;81:680-3.

9. Kalan M. Evaluation of modified alvarado score in diagnosis of acute appendicitis a prospective study. Ann R CollSurjEngl. 1994;76:418-9.

10. Jawaid A, Asad A. Clinical scoring system a valuable tool for decision making in cases of acute appendicitis. J Pak Med Assoc. 1999;49(10);254-9. 
11. Chan MY, Teo BS. The alvarado score and acute appendicitis. Ann Acad Med Singapore. 2001;30(5):510-2.

12. Khan I ,Rehman A. Application of alvarado scoring in diagnosis of acute appendicitis .J Ayub Med Coll Abbottabad. 2005;17(3):41-4.
13. Denizbasi A, Unleur EE. The role of emergency medicine resident using the alvarado score in the diagnosis of acute appendicitis copmpared with emergency general surgery rsidentEur $\mathbf{J}$ Emerg Med. 2003;10(4):296-301.

Cite this article as: Koppad SN, Kodliwadmath H, Desai M. Analysis of application and diagnostic importance of alvarado scoring system in patients with right lower quadrant abdominal pain. Int Surg J 2016;3:1240-3. 